\title{
Perkembangan Pengelolaan Arsip Elektronik di Indonesia: Tinjauan Pustaka Sistematis
}

\author{
Fajar Nyfantoro', Tamara Adriani Salim², Anon Mirmani ${ }^{3}$ \\ ${ }^{123}$ Departemen Ilmu Perpustakaan dan Informasi, Fakultas IImu Budaya, Universitas Indonesia
}

\begin{abstract}
Introduction. In Indonesia, technology has developed in various fields, this study explores the management of archives in Indonesian institutions still uses conventional archives or manages records electronically. The result of our findings also convey information on the development of electronic records management that has been carried out through a systematic literature review. A systematic literature review method was used for exploring electronic records management study. The use of this method is designed to search for, assess, and synthesize the best available evidence. The goal is to get informative, evidence-based answers related to the research questions.The research will be analyzed based on the theory of Population, Intervention, Comparison, Outcomes and Context (PICOC). Carried out through a systematic literature review method, our results found 20 documents that had links with electronic archive management activities. The institution applies electronic archive management by using software technology such as computer-based applications, Android-based applications on mobile phones, and website-based network applications to various processes of archiving activities. Conclusion Our results suggest that the management of institutional records in Indonesia should follow the development by implementing electronic management.
\end{abstract}

Submitted: 05/08/2019

Received: 22/01/2020

*Correspondence:

Fajar Nyfantoro

nyfan@pmbs.ac.id

KEYWORDS:

electronic archive management

systematic literature review

Indonesia

\section{INTISARI}

Teknologi di Indonesia sudah berkembang pesat di berbagai bidang. Penelitian ini menginvestigasi pengelolaan arsip pada institusi di Indonesia menggunakan arsip konvensional atau pengelolaan arsip secara elektronik. Selain itu, hasil studi ini juga ingin menyampaikan informasi perkembangan pengelolaan arsip elektronik yang telah dilakukan saat ini melalui tinjauan pustaka pada artikel-artikel jurnal ilmiah. Penelitian pengelolaan arsip elektronik ini dilakukan dengan menggunakan metode tinjauan literature sistematis. Penggunaan metode ini dirancang untuk mencari, menilai, dan mensintesis bukti terbaik yang tersedia. Tujuannya untuk mendapatkan jawaban informatif yang berbasis bukti terkait sesuai dengan pertanyaan penelitian. Penelitian yang akan digunakan akan dianalisis berdasarkan teori Population, Intervention, Comparison, Outcomes and Context (PICOC). Penelitian yang dilakukan dengan metode tinjauan pustaka sistematis ini menemukan sebanyak 20 dokumen yang mempunyai hubungan dengan kegiatan pengelolaan arsip elektronik. Hal ini terlihat dari institusi yang mengaplikasikan pengelolaannya dengan menggunakan teknologi perangkat lunak seperti aplikasi berbasis komputer, aplikasi berbasis android pada handphone, dan aplikasi berbasis jaringan website yang diterapkan pada berbagai macam proses kegiatan pengarsipan. Pengelolaan arsip institusi di Indonesia sudah selayaknya mengikuti perkembangan zaman dengan menerapkan pengelolaan secara elektronik. 


\section{PENDAHULUAN}

Pada saat ini di Indonesia sudah mengalami perkembangan yang sangat maju dan mulai memasuki era digital yang ditandai dengan perkembangan teknologi informasi yang meningkat dan bergerak cepat. Hampir semua bidang didalam kehidupan masyarakatnya dipengaruhi oleh teknologi yang menggunakan komputer dan jaringan internet. Saat ini internet telah menjadi rujukan utama dan menjadi pusat dari segala informasi yang dibutuhkan oleh manusia. Internet adalah hubungan antar komputer yang saling berjaringan dari seluruh dunia. Menurut Purbo (2006), secara sederhana internet adalah jaringan dari jaringan. Konsep yang saling terhubung ini menjadikan internet sebagai jaringan yang sangat besar, sehingga memiliki banyak manfaat antara lain saling bertukar informasi. Kadir (2003) mengatakan bahwa sebuah organisasi dapat melakukan pertukaran informasi secara internal ataupun melakukan pertukaran informasi secara eksternal dengan organisasi lain.

Perkembangan teknologi komputer dan internet yang terjadi ini, secara tidak langsung mempengaruhi masyarakat dalam memenuhi kebutuhan informasi yang meningkat. Kebutuhan informasi di masyarakat merupakan sesuatu yang tidak dapat diabaikan dan telah menjadi bagian dalam kegiatan sehari-hari. Informasi yang berada di tengah kehidupan masyarakat tersedia dalam berbagai macam dokumen berbentuk tercetak maupun elektronik yang dikenal dengan istilah arsip.

Arsip adalah catatan yang berfungsi sebagai memori di dalam suatu institusi. Keberadaan arsip ini mempunyai tujuan untuk mengumpulkan informasi dan memudahkan temu kembalinya. Jadi arsip mempunyai peran penting pada suatu institusi yaitu sebagai salah satu jenis sumber informasi. Hal ini menjadikan arsip dapat digunakan sebagai bahan bukti didalam pengambilan keputusan secara tepat. Supaya semua itu dapat berjalan dengan fungsinya maka dibutuhkan suatu system pengolahan kearsipan yang dapat memudahkan di dalam melakukan pengelolaan dan penyimpanannya.

Pengaruh perkembangan teknologi computer dan internet dapat mempengaruhi pada bidang kearsipan bahwa Internet berpengaruh pada (1) perubahan cara bekerja, (2) perubahan cara berkomunikasi, (3) perubahan persepsi tentang efisiensi, (4) perubahan dalam penciptaan, pengelolaan dan penggunaan informasi/arsip, dan (5) perubahan bagi arsiparis dalam mengelola arsip (Desi Pratiwi, 2012). Hal ini memberikan dampak langsung pada kegiatan pengelolaan arsip, sehingga pengelolaan arsip dapat dilakukan secara elektronik. Teknologi informasi yang dapat digunakan untuk melakukan pengeolaan arsip saat ini yaitu dikenal dengan nama Electronic Filing System (EFS). Sistem pengarsipan secara elektronik ini memanfaatkan seperangkat komputer yang akan mempermudah dan mempercepat proses pengelolaan kearsipan. Pemanfaatan komputer didalam proses pengarsipan dapat merubah format arsip tercetak menjadi elektronik.

Pemerintah Indonesia juga telah mendukung dan membuat landasan untuk melakukan pengelolaan arsip secara elektronik hal ini dapat dirujuk pada peraturan perundang-undangan yang telah dikeluarkan yaitu (Sambas dan Hendri, 2016),

1. Instruksi Presiden Republik Indonesia No. 03 Tahun 2003 tentang Kebijakan dan Strategi Nasional Pembangunan E-Government, yang menyatakan bahwa: "Pemerintah harus mampu memanfaatkan kemajuan teknologi informasi untuk 
menciptakan kemampuan mengolah, mengelola, menyalurkan, dan mendistribusikan informasi dan pelayanan publik."

2. Undang-Undang Republik Indonesia No. 11 Tahun 2008 tentang Informasi dan Transaksi Elektronik, pada Pasal 5 ayat (3), yang menyatakan bahwa: "Informasi elektronik dan/atau Dokumen Elektronik dinyatakan sah apabila menggunakan sistem elektronik sesuai dengan ketentuan yang diatur dalam undang-undang ini."

3. Undang-Undang Republik Indonesia No. 14 Tahun 2008 tentang Keterbukaan Informasi Publik, pada Pasal 7, yang menyatakan bahwa:

a) "Badan publik wajib menyediakan, memberikan, dan/atau menerbitkan informasi publik yang berada di bawah kewenangannya kepada Pemohon informasi publik selain informasi publik yang dikecualikan sesuai ketentuan"

b) "Badan publik wajib menyediakan informasi publik yang akurat, benar, dan tidak menyesatkan."

c) "Untuk melaksanakan kewajiban sebagaimana dimaksud pada ayat (2), badan publik harus membangun dan mengembangkan sistem informasi dan dokumentasi untuk mengelola Informasi Publik secara baik dan efisien sehingga dapat diakses dengan mudah."

4. Undang-Undang Republik Indonesia No. 43 Tahun 2009 tentang Kearsipan, pada Pasal 40 ayat (1), yang menyatakan bahwa: "Pengelolaan arsip dinamis dilaksanakan untuk menjamin ketersediaan arsip dalam penyelenggaraan kegiatan sebagai bahan akuntabilitas kinerja dan alat bukti yang sah berdasarkan suatu sistem yang memenuhi persyaratan: (a) andal; (b) sistematis; (c) utuh; menyeluruh; dan (d) sesuai dengan norma, standar, prosedur, dan kriteria."

Berdasarkan penelitian sebelumnya yang telah dilakukan di dalam bidang kearsipan khususnya yang membahas mengenai pengelolaan arsip elektronik yaitu antara lain :

1. Studi yang dilakukan oleh Robby Yuli Endra, Usman Rizal, Fenty Ariani yang berjudul, "E-Arsip Berbasis Image Archives Management Process Model Untuk Meningkatkan Efektifitas Pengelolaan Arsip"

2. Studi yang dilakukan oleh Sambas Ali Muhidin, Budi Santoso, dan Hendri Winata yang berjudul "Pengelolaan Arsip Digital"

3. Studi yang dilakukan oleh Rifauddin, M. yang berjudul "Pengelolaan Arsip Elektronik Berbasis Teknologi"

4. Studi yang dilakukan oleh Habiburrahman yang berjudul "Penggunaan Perangkat Lunak Dalam Pengelolaan Arsip Konvensional Dan Elektronik"

Serta melihat perkembangan teknologi yang ada saat ini ditambah dengan dukungan pemerintah dalam pengelolaan arsip secara elektronik. Hasil studi ini ingin mengetahui apakah pengelolaan arsip pada institusi di Indonesia masih menggunakan arsip konvensional atau sudah melakukan pengelolaan arsip secara elektronik. Selain itu hasil studi ini juga ingin menyampaikan informasi pengelolaan arsip elektronik yang telah dilakukan saat ini dan telah dipublikasikan pada artikel-artikel jurnal ilmiah. Penulis berharap hasil studi ini dapat salah satu referensi pada hasil studi berikutnya dan dapat melengkapi informasi pada bidang kearsipan. 


\section{TINJAUAN PUSTAKA}

Ada beberapa penelitian sebelumnya yang membahas mengenai pengelolaan arsip elektronik ini. Hasil penelitian tersebut ditemukan dalam basis data jurnal online karena telah dipublikasikan yaitu antara lain :

1. "E-Arsip Berbasis Image Archives Management Process Model Untuk Meningkatkan Efektifitas Pengelolaan Arsip" merupakan hasil studi yang dilakukan oleh Robby Yuli Endra, Usman Rizal, dan Fenty Ariani yang dipublikasikan pada Jurnal EXPLORE Vol. 7, Nomor 1 Tahun 2016. Penelitian ini berisi mengenai transisi perubahan pengelolaan arsip dari metode manual hingga menggunakan metode elektronik. Sistem aplikasi yang dipakai ini dirancang dan dilengkapi dengan fitur notifikasi melalui sms dan e-mail,

2. Studi yang dilakukan oleh Sambas Ali Muhidin, Budi Santoso, dan Hendri Winata yang berjudul "Pengelolaan Arsip Digital" yang dipublikasikan pada Jurnal Pendidikan Bisnis dan Manajemen (JPBM) Vol. 2, Nomor 3, Tahun 2016. Penelitian ini berisi mengenai cara dan peralatan yang dibutuhkan dalam melakukan pengelolaan arsip secara elektronik.

3. Studi yang dilakukan oleh Rifauddin, M. yang berjudul "Pengelolaan Arsip Elektronik Berbasis Teknologi" yang dipublikasikan pada Jurnal Ilmu Perpustakaan, Informasi dan Kearsipan - Khizanah Al-Hikmah Vol. 4 No. 2 tahun 2016. Penelitian ini berisi mengenai pengaplikasian teknologi pada pengelolaan arsip elektronik yang berada pada institusi di Indonesia.

4. Studi yang dilakukan oleh Habiburrahman yang berjudul "Penggunaan Perangkat Lunak Dalam Pengelolaan Arsip Konvensional Dan Elektronik" yang dipublikasikan pada Jurnal Ilmu Perpustakaan, Informasi dan Kearsipan - Khizanah Al-Hikmah Vol. 4 No. 2 tahun 2016. Penelitian ini berisi mengenai pengelolaan arsip dalam bentuk konvensional dan elektronik, serta perangkat lunak yang digunakannya dengan tujuan untuk mempermudah layanan kearsipan dalam menjalankan tugasnya.

\section{Definisi arsip}

Kata arsip pertama kali digunakan oleh bangsa Yunani yaitu "Archium" yang memiliki arti sebagai peti penyimpanan atau "Arkheion" yang berarti Balai Kota. Pada zaman Yunani istilah arsip menunjukkan kepada tempat atau lokasi penyimpanan dokumen. Tetapi seiring perkembangan zaman, istilah tersebut saat ini bergeser menjadi dokumen itu sendiri. Seperti yang didefinisikan oleh bangsa Inggris yang menyebut istilah arsip sebagai "Archive" yang berarti sebagai kumpulan warkat atau rekod dokumen itu sendiri. Sedangkan menurut SO 15489-1 (Record Managementart 1: General) arsip adalah "dokumen yang dibuat, diterima, dan disimpan sebagai bukti dan informasi oleh sebuah badan, organisasi, atau orang, untuk memenuhi kewajiban hukum atau dalam transaksi bisnis."

\section{Definisi arsip elektronik}

Kata arsip elektronik diambil dari istilah Electronic Archive (e-archive) yang berarti sistem pengumpulan dan penyimpanan informasi dalam bentuk dokumen elektronik yang mempunyai tujuan supaya mudah dilihat, dikelola, ditemukan dan dipakai kembali. Menurut International Council of Archives (ICA) arsip elektronik mempunyai arti yaitu sebagai dokumen yang mudah untuk dirubah, dipindahkan atau diolah menggunakan komputer. Arsip elektronik menurut National Archives and 
Record Administration (NARA) adalah arsip yang disimpan dan diolah dalam suatu format dengan menggunakan komputer. Sedangkan definisi arsip elektronik menurut Standards of Electronic Records Filing and Management China yaitu sebagai dokumen yang diciptakan oleh perangkat digital, dalam lingkup digital dan format digital, mengandalkan perangkat digital seperti komputer untuk membaca dan pemrosesan, dan dapat didistribusikan melalui jaringan komunikasi. Dari beberapa definisi arsip elektronik di atas, dapat ditarik kesimpulan yaitu arsip elektronik merupakan dokumen-dokumen informasi yang dibuat, direkam, diolah atau dialihmediakan dengan menggunakan peralatan elektronik dan dapat disimpan dalam berbagai format elektronik. Format arsip elektronik tersebut dapat dibagi menjadi 4 (empat) kategori yaitu : berbasis teks; berbasis gambar; berbasis audio; dan berbasis audio video. (Habiburrahman, 2016)

\section{Definisi tinjauan pustaka sistematis}

Tinjauan pustaka sistematis atau dalam Bahasa Inggris disebut sebagai "Systematic Literature Review" (SLR) merupakan suatu metode yang digunakan untuk mengidentifikasi, menganalisis, dan menginterpretasikan seluruh hasil temuan data pada suatu penelitian serta untuk menjawab pertanyaan dari penelitian yang telah ditentukan sebelumnya (Kitchenham dan Charters, 2007). Metode SLR ini harus dilakukan dengan cara sistematis dan mengikuti alur tahapan dari setiap bagian serta protokolnya sehingga dapat proses tinjauan pustaka dapat terhindar dari pemahaman peneliti yang bersifat subyektif. Metode SLR ini sebelumnya adalah suatu metode yang biasa digunakan oleh peneliti pada bidang farmasi dan kedokteran. Pada tahun 2007, metode SLR ini mulai diperkenalkan oleh Barbara Kitchenham ke dunia teknologi computer melalui papernya yang berjudul "Guidelines in performing Systematic Literature Reviews in Software Engineering."

\section{METODE PENELITIAN}

Penelitian pengelolaan arsip elektronik ini dilakukan dengan menggunakan metode tinjauan pustaka sistematis (Kitchenham dan Charters, 2007; Okoli dan Schabram, 2010). Penggunaan metode ini dirancang untuk mencari, menilai, dan mensintesis bukti terbaik yang tersedia. Hal ini dilakukan untuk mendapatkan jawaban informatif yang berbasis bukti terkait sesuai dengan pertanyaan penelitian. Teori tinjauan pustaka sistematis ini mempunyai 3 (tiga) bagian yang terdiri dari a) tahapan perencanaan; b) tahapan pelaksanaan; c) dan tahapan pelaporan (lihat Gambar 1).

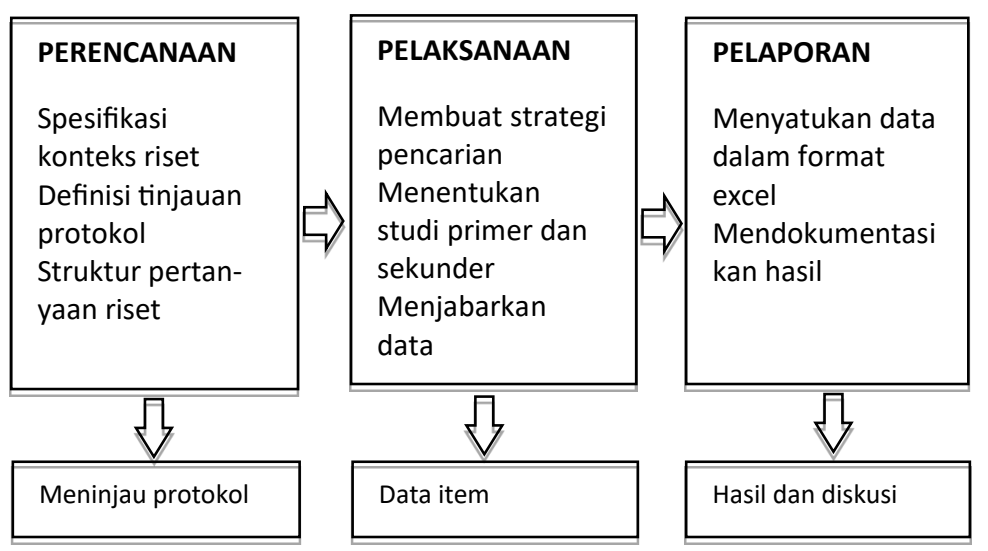

Gambar 1. Tahapan tinjauan sistematis 
Dimulai dari tahapan perencanaan yang akan menyeleksi basis data jurnal elektronik yang akan digunakan, dengan harapan akan menemukan jawaban dari pertanyaan penelitian. Dilanjutkan dengan tahapan pelaksanaan yang akan melakukan strategi pencarian data menggunakan kata kunci serta melakukan inklusi dan enklusi data yang telah ditemukan. Diakhiri dengan tahapan pelaporan yang akan menyimpulkan dari semua hasil data temuan dan memberikan penilaian atas hasil penelitian tersebut.

\section{Pertanyaan penelitian}

Pada tahapan perencanaan ini, peneliti membuat pertanyaan penelitian sebagai bentuk penegasan masalah yang jawabannya akan dicari dalam riset ini.. Penelitian ini akan menggunakan pertanyaan penelitian yang disusun berdasarkan teori Population, Intervention, Comparison, Outcomes and Context (PICOC) seperti yang ditunjukkan Tabel 1 (Petticrew dan Robert, 2006).

Tabel 1. Identifikasi ruang lingkup pertanyaan penelitian

\begin{tabular}{|l|l|}
\hline Kriteria & Ruang Lingkup \\
\hline Population & Data-data pengelolaan arsip elektronik \\
\hline Intervention & Pembatasan dalam pengelolaan arsip elektronik \\
\hline Comparison & Not applicable \\
\hline Outcomes & $\begin{array}{l}\text { Tipe dan kriteria dari data-data pengelolaan arsip el- } \\
\text { ektronik }\end{array}$ \\
\hline Context & $\begin{array}{l}\text { Ulasan dari hasil investigasi dari data-data pengelolaan } \\
\text { arsip elektronik }\end{array}$ \\
\hline
\end{tabular}

Pertanyaan penelitian dapat dibagi menjadi 2 (dua) kategori yaitu pertanyaan umum (General Research Question) dan pertanyaan khusus (Specific Research Question). Pertanyaan umum tidak dapat dijawab secara langsung karena memiliki sifat umum yang lebih abstrak sedangkan pertanyaan khusus dapat dijawab secara langsung karena mengacu pada data-data dari hasil penelitian.

Hasil studi ini memiliki 2 (dua) pertanyaan penelitian (RQ) yang dirancang sesuai dengan kategori pertanyaan penelitian dan batasan ruang lingkup yang terdapat pada Tabel 1, yaitu

- RQ1: Berapa banyak hasil studi yang telah dilakukan mengenai pengelolaan arsip elektronik di Indonesia?

- $\quad$ RQ2: Apa saja konsep dan model yang telah digunakan institusi di Indonesia dalam melakukan pengolahan arsip elektroniknya?

\section{Strategi pencarian}

Pada tahapan pelaksanaan ini, peneliti membuat rencana strategi yang dilakukan untuk merumuskan istilah yang akan digunakan sebagai kata kunci pencarian, kemudian menentukan pilihan database jurnal online yang akan dijadikan media dalam pencarian, memasukkan kriteria inklusi dan enklusi pada hasil data temuan, serta memberikan penilaian dan pertimbangan khusus pada objek data yang akan digunakan di dalam pembahasan penelitian.

\section{Sumber literatur}

Hasil data temuan artikel yang digunakan hanya berasal dari 1 (satu) sumber literatur yaitu didapatkan portal GARUDA (Garba Rujukan Digital). Garuda merupakan salah satu database jurnal online yang berisi kumpulan informasi dari berbagai bidang studi. Sedangkan artikel jurnal online yang digunakan akan diseleksi berdasarkan tahun terbitannya dan dipublikasikan dari 2014 hingga 2019. 


\section{Kriteria inklusi dan enklusi}

Inklusi dan enklusi ini digunakan untuk menyeleksi berdasarkan kriteria dan memfokuskan pada artikel journal online yang sesuai dengan kebutuhan peneliti. Point dari kriteria inklusi dan enklusi yang diberikan akan ditampilkan seperti pada Tabel 2.

Tabel 2. Kriteria inklusi dan enklusi

\begin{tabular}{|l|l|}
\hline Inklusi & Enklusi \\
\hline $\begin{array}{l}\text { Artikel jurnal mengenai } \\
\text { arsip digital }\end{array}$ & Artikel jurnal non hasil riset \\
\hline $\begin{array}{l}\text { Artikel jurnal berbahasa In- } \\
\text { donesia }\end{array}$ & Artikel jurnal sebelum 2014 \\
\hline Artikel jurnal hasil riset & Artikel jurnal duplikasi \\
\hline Artikel jurnal full text & Artikel jurnal hanya abstrak \\
\hline $\begin{array}{l}\text { Artikel jurnal periode 2014- } \\
2019\end{array}$ & \\
\hline
\end{tabular}

Penelitian ini menghasilkan sebuah tinjauan sistematis yang telah dilakukan melalui review artikel jurnal online yang membahas mengenai pengelolaan arsip elektronik di Indonesia. Proses pencarian artikel jurnal online ini dilakukan melalui website Portal GARUDA. Dari hasil pencarian awal dengan menggunakan kata kunci "Pengelolaan Arsip" yang dicari pada judul artikel ditemukan sebanyak 145 (seratus empat puluh lima) dokumen jurnal yang terdiri dari format full text dan format abstract. Peneliti berusaha untuk menyeleksi kembali hasil pencarian pada artikel jurnal yang dipublikasikan dalam periode tahun 2014-2019. Hasil akhirnya ditemukan artikel jurnal online sebanyak 125 (seratus dua puluh lima) dokumen. Langkah terakhir untuk lebih memfokuskan hasil pencarian supaya dapat menjawab pertanyaan penelitian, data jurnal online hasil temuan ini dibatasi hanya pada artikel yang full text sehingga ditemukan sebanyak 38 (tiga puluh delapan) dokumen. Jadi hasil akhir pencarian jurnal yang berkaitan tentang Pengelolaan Arsip dalam 2014-2019 dan tersedia dalam bentuk full text pada website portal garuda ialah sebanyak 38 (tiga puluh delapan) dokumen. Artikel jurnal online inilah yang dijadikan sebagai bahan di dalam penelitian yang prosesnya seperti yang ditampilkan dalam bentuk bagan alur pada Gambar 1.

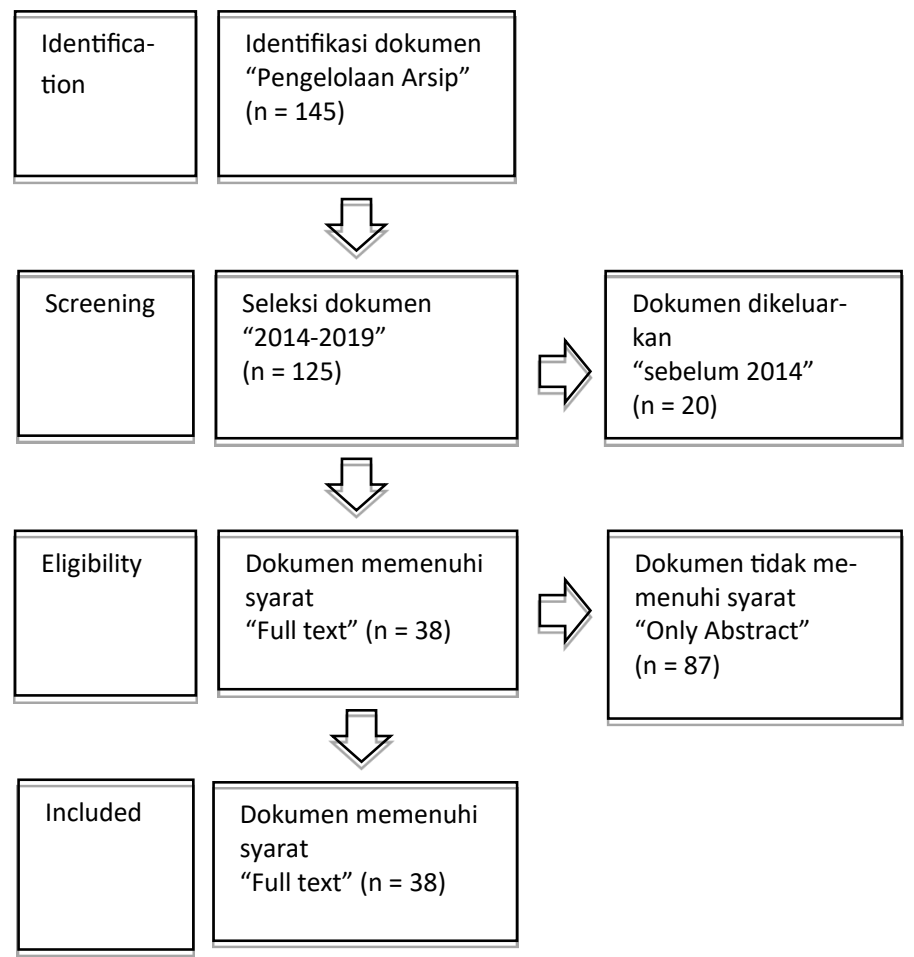

Gambar 2. Proses tinjauan sistematis 


\section{HASIL DAN PEMBAHASAN}

\section{RQ1: Berapa banyak hasil studi yang telah dilakukan mengenai pengelolaan arsip elektronik di Indonesia?}

Berdasarkan hasil penelusuran artikel pada portal GARUDA, penelitian yang dilakukan dengan metode tinjauan pustaka sistematis ini menemukan sebanyak 38 (tiga puluh delapan) dokumen yang mempunyai hubungan dengan kegiatan pengelolaan arsip di Indonesia. Dengan hasil temuan data ini, peneliti berusaha untuk menganalisa lebih dalam seluruh isi dokumen tersebut. Tujuannya untuk mengetahui tentang hasil studi yang membahas mengenai pengelolaan arsip elektronik. Dari 38 (tiga puluh delapan) dokumen itu, peneliti membagi hasil temuan data menjadi 3 (tiga) jenis pembahasan yaitu: a) manusia yang berhubungan dengan kegiatan pengelolaan arsip; b) sistem pengelolaan arsip secara manual; c) sistem pengelolaan arsip elektronik.

Untuk hasil studi yang membahas mengenai manusia yang berhubungan dengan kegiatan pengelolaan arsip elektronik ditemukan sebanyak 6 (enam) dokumen yang terdiri dari:

1. "Fungsi Pengelolaan Arsip Dalam Rangka Meningkatkan Efektivitas Kerja Pada Balai Pengelolaan Hutan Mangrove Wilayah II", (Suyono, 2014)

2. "Persepsi Pegawai Terhadap Pengelolaan Arsip Di Kantor Kejaksaan Negeri Bukittinggi", (Iskandar, 2015)

3. "Pengaruh Sumber Daya Manusia Dan Ruang Penyimpanan Arsip Dalam Melakukan Kegiatan Pengelolaan Kearsipan Di Pusat Reaktor Serba Guna", (Suhana, 2016)

4. "Kompetensi Arsiparis Dalam Pengelolaan Kearsipan Terhadap Pemenuhan Kebutuhan Informasi Masyarakat", (Ardyawin, 2017)

5. "Pengawasan Kepala Sekolah Terhadap Pengelolaan Arsip Di Sekolah", (Munawaroh, 2018)

6. "Upaya Meningkatkan Kinerja Pegawai Tata Usaha (TU) Dalam Pengelolaan Arsip Melalui Kegiatan Supervisi Manajerial Pada Madrasah Tsanawiyah Swasta Darul Istiqomah Padangsidimpuan", (Yusron, 2019)

Untuk hasil studi yang membahas mengenai sistem pengelolaan arsip secara manual ditemukan sebanyak 12 (dua belas) dokumen yang terdiri dari:

1. "Pengelolaan Arsip Dinamis Inaktif di Kantor Dinas Koperasi dan Usaha Mikro Kecil dan Menengah (UMKM) Provinsi Sumatera Barat", (Yanti, Nelisa, 2014)

2. "Model Mekanisme Pengelolaan Arsip Di Kantor Perpustakaan, Arsip Dan Dokumentasi Kabupaten Tulungagung", (Hariyanto, 2015)

3. "Pengelolaan Arsip PTBBN Dalam Pelaksanaan Reformasi Birokrasi Batan", (Jumiyati, 2015)

4. “Pengelolaan Arsip Inaktif Dalam Upaya Mendukung Layanan Informasi Di Kantor Arsip Dan Perpustakaan Daerah Kabupaten Purworejo", (Rahmawati, Ismiyati, 2016)

5. "Sistem Pengelolaan Arsip Debitur di PT Bank Negara Indonesia (Persero) Tbk. Kantor Cabang Utama Padang", (Hamdani, Marlini, 2016)

6. "Pengelolaan Arsip Di Kantor Badan Pengendalian Dampak Lingkungan Daerah Kota Padang", (Putri, 2016)

7. "Pembuatan Standard Operating Procedure (SOP) Pengelolaan Arsip Dinas Kearsipan dan Perpustakaan Provinsi Sumatera Barat", (Daini, Marlini, 2017)

8. "Pengelolaan Arsip Pada Aparatur Kelurahan Muara Fajar Barat Kecamatan Rumbai Kota Pekanbaru", (Harsini, Nasution, 2017)

9. "Reorientasi Sistem Pengelolaan Arsip Dinamis", (Iskandar, 2018)

10. "Pengelolaan Arsip Di Sekolah Tinggi Ilmu Hukum Sumpah Pemuda Palembang”, (Indriani, 2018)

11. "Pengelolaan arsip di media massa radio Global 101.0 FM Palembang", (Andrianza, 2018)

12. "Pengelolaan arsip dinamis (surat masuk dan surat keluar) di Universitas Indo Global Mandiri", (Ramadani, 2018)

Untuk hasil studi yang membahas mengenai sistem pengelolaan arsip elektronik ditemukan sebanyak 20 (dua puluh) dokumen yang terdiri dari:

1. "Sistem Informasi Pengelolaan Arsip Statis Pada Badan Arsip Dan Perpustakaan Provinsi 
Jawa Tengah Menggunakan Vector Space Model”, (Kafatan, Riyanto, 2014)

2. "Pengembangan Model Pengelolaan Arsip (Surat) dan Dokumen Pemerintah Berbasis Web pada Kantor Pemerintah Kabupaten Sidrap Provinsi Sulawesi Selatan", (Imasita, Gunawan, 2015)

3. "Aplikasi Pengelolaan Arsip Surat Berdasarkan Peraturan Bersama Kepala Anri Nomor 18 Th. 2009", (Zakiah, Supriatna, 2015)

4. “Pengelolaan Arsip Digital”, (Muhidin, Ali, 2016)

5. "Penggunaan Perangkat Lunak Dalam Pengelolaan Arsip Konvensional Dan Elektronik", Habiburrahman, 2016)

6. "E-Arsip Berbasis Image Archives Management Process Model untuk Meningkatkan Efektifitas Pengelolaan Arsip", (Endra, Rizal, 2016)

7. "Penggunaan System Application and Product in Data Processing (SAP) dalam Pengelolaan Data Arsip pada Bagian Keuangan PT. Telkom Witel Sum-Bar", (Yona, Marlini, 2016)

8. "Sistem Pengelolaan Arsip Unit dalam Negeri dan Kliring di PT. Bank Negara Indonesia (Persero) Tbk Kantor Cabang Utama Padang", (Juwita, Rahmah, 2016)

9. "Pengelolaan Arsip Vital pada Kantor Arsip Universitas Indonesia”, (Lasambouw,Fajriani, 2016)

10. "Menciptakan Pengelolaan Arsip Surat Kabar yang Andal (Studi Kasus Depo Arsip Suara Merdeka)", (Sadhyoko, 2016)

11. "Persepsi kegunaan pengelolaan arsip digital menggunakan SIKD (sistem informasi kearsipan dinamis)", (Tjiptasari, 2017)

12. "Pengelolaan Arsip Elektronik Berbasis Teknologi", (Rifauddin, 2017)

13. "Optimalisasi Pengelolaan Kearsipan Melalui Arsip-E Di Direktorat Jenderal Guru Dan Tenaga Kependidikan", (Soesilo, 2017)

14. "Evaluasi Biaya Pengembangan Sistem Informasi Pengelolaan Arsip Surat (SIPAS) Menggunakan Function Point dan Object Point (Studi Kasus : PT Sekawan Media Informatika)", (Laksamana, Perdanakusuma, 2018)

15. "Pengelolaan Arsip Statis pada Badan Perpustakaan, Arsip dan Dokumentasi Provinsi Sumatera Utara", (Nuraini, 2018)

16. “Pengelolaan arsip di Detik Sumatera Selatan", (Mustika, 2018)

17. "Sistem Pengelolaan Arsip Dengan Menerapkan Manajemen Akses User Berbasis Web Pada YPPALB B (Tunarungu Wicara) Kota Magelang", (Nugraha, Adi, 2018)

18. "Aplikasi Sistem Informasi Pengelolaan Arsip pada Unit Pelayanan Pajak dan Retribusi Daerah Palmerah Jakarta", (Fitriani, Pakpahan, 2018)

19. "Aplikasi Manajemen Surat Untuk Pengelolaan Arsip Dinamis Aktif Di PT. PLN (Persero) App Salatiga", (Damara, Arfa, 2018)

20. "Aplikasi Pengelolaan Arsip Inaktif Berbasis Android pada Kantor Pusat Direktorat Jenderal Bea dan Cukai", (Leidiyana, Ridwan, 2019)

Pemilahan hasil data temuan ini sangat memudahkan peneliti untuk menganalisa isi dokumen dan menjawab semua pertanyaan penelitian. Dari 38 (tiga puluh delapan) dokumen yang telah ditemukan, jawaban untuk RQ1 berdasarkan pada hasil analisa isi dokumen yang memiliki hubungan dengan pengelolaan arsip elektronik. Hasil akhirnya ditemukan yaitu sebanyak 20 (dua puluh) dokumen mengenai pengelolaan arsip elektronik.

\section{RQ2: Apa saja konsep dan model yang telah digunakan institusi di Indonesia dalam melakukan pengolahan arsip elektroniknya?}

Penelitian ini juga melakukan analisa perkembangan konsep dan model pengelolaan arsip elektronik yang telah dilakukan pada institusi di Indonesia. Dari hasil 20 (dua puluh) dokumen yang telah ditemukan, peneliti berusaha menggali informasi lebih dalam dengan menganalisa seluruh isi dokumen. Hasil analisa mendalam ini menemukan bahwa perkembangan pengelolaan arsip elektronik sudah mengalami kemajuan dengan penerapan konsep dan model pengelolaan secara elektronik pada institusi di Indonesia.

Berikut adalah hasil temuan data institusi yang telah melakukan pengelolaan arsipnya secara elektronik beserta konsep dan model yang digunakannya :

1. Badan Arsip dan Perpustakaan di Provinsi Jawa Tengah menggunakan sistem aplikasi "Vector Space Model" (VSM) yang berbasis website untuk pengelolaan arsip statis. 
2. Kantor Pemerintah Kabupaten Sidrap di Provinsi Sulawesi Selatan menggunakan aplikasi Sistem Pengelolaan Arsip Dokumen Pemerintah (SIPADOP) yang berbasis website untuk mengelola arsip surat dan dokumen pemerintahan.

3. Universitas Bandar Lampung menggunakan sistem aplikasi "Image Archives Management Process Model" (IAMPM) yang berbasis website untuk meningkatkan efektifitas pengelolaan arsip foto.

4. PT. Telkom Witel Sum-Bar menggunakan "System Application and Product in Data Processing" (SAP) untuk pengelolaan arsip data keuangan.

5. PT. Bank Negara Indonesia (Persero) Tbk Kantor Cabang Utama Padang menggunakan sistem aplikasi BNI ICONS untuk pengelolaan arsip daftar nama debitur.

6. Kantor Arsip Universitas Indonesia menggunakan aplikasi Sistem Elektronik Kearsipan (SEKAR) untuk pengelolaan arsip vital.

7. Suara Merdeka menggunakan Depo Arsip untuk pengelolaan arsip yang berupa artikel berita surat kabar.

8. Direktorat Jenderal Guru Dan Tenaga Kependidikan menyatukan 3 (tiga) sistem yaitu Aplikasi SAP, Aplikasi E-Office, dan Aplikasi E-Arsip untuk pengembangan aplikasi sistem persuratan dan kearsipan yang terintegrasi.

9. PT. Sekawan Media Informatika menggunakan perangkat lunak "Function Point" dan "Object Point" untuk Pengembangan Sistem Informasi Pengelolaan Arsip Surat (SIPAS)

10. Badan Perpustakaan, Arsip dan Dokumentasi di Provinsi Sumatera Utara menggunakan Sistem Informasi Kearsipan Statis (SIKS) untuk menyusun database dan mengunggah arsip ke dalam sistem jaringan.

11. Kantor Detik di Provinsi Sumatera Selatan menggunakan database repository untuk penyimpanan dan sarana temu kembali arsipnya yang dapat diakses melalui website dan sistem aplikasi pada telepon genggam.

12. Yayasan Pendidikan dan Penyantunan Anak Luar Biasa Bagian B (YPPALB-B) di Kota Magelang menggunakan Manajemen Akses User yang berbasis website.

13. Unit Pelayanan Pajak dan Retribusi Daerah Palmerah Jakarta menggunakan sistem aplikasi berbasis website untuk pengelolaan arsip elektroniknya.

14. PT. PLN (Persero) App Salatiga menggunakan Aplikasi Manajemen Surat untuk pengelolaan arsip dinamis.

15. Kantor Pusat Direktorat Jenderal Bea dan Cukai menggunakan sistem aplikasi berbasis android untuk pengelolaan arsip inaktif.)

\section{KESIMPULAN}

Pengelolaan arsip elektronik di Indonesia telah didukung oleh pemerintah dengan dikeluarkannya Undang-Undang Republik Indonesia No. 11 tahun 2008 tentang informasi dan transaksi elektronik. Arsip elektronik merupakan arsip dengan format baru yang pengelolaannya menggunakan teknologi komputer. Pengelolaan arsip di institusi yang selama ini dilakukan secara manual sebaiknya perlu dirubah secara elektronik untuk mengikuti perkembangan zaman. Teknologi yang ditawarkan saat ini memberi banyak kemudahan dalam melakukan pengelolaan arsip secara elektronik. Sudah banyak sistem aplikasi perangkat lunak tersedia sehingga dapat meningkatkan kualitas pengelolaan arsip elektronik. Penelitian ini telah mengidentifikasi institusi di Indonesia yang telah mengaplikasikan pengelolaan arsipnya secara elektronik seperti institusi pemerintah, institusi swasta, institusi perbankan, dan institusi pendidikan. Pengelolaan arsip elektronik di institusi ini telah menggunakan teknologi perangkat lunak seperti aplikasi berbasis komputer, aplikasi berbasis android pada telepon genggam, dan aplikasi website berbasis jaringan internet. Sistem aplikasi ini diterapkan pada berbagai macam proses kegiatan pengarsipan yang ada di institusi tersebut, seperti pengelolaan arsip statis, pengelolaan surat dan dokumen pemerintah, pengelolaan dokumen foto, pengelolaan data keuangan, pengelolaan arsip vital, pengelolaan surat kabar, dan pengelolaan arsip inaktif.

\section{DAFTAR PUSTAKA}


Andrianza, Yogi. (2018). Pengelolaan arsip di media massa radio Global 101.0 FM Palembang. IQRA: Jurnal Perpustakaan dan Informasi Vol. 12, No. 1. http://jurnal.uinsu.ac.id/ index.php/iqra/article/view/1848

Ardyawin, Iwin. (2017). Kompetensi Arsiparis Dalam Pengelolaan Kearsipan Terhadap Pemenuhan Kebutuhan Informasi Masyarakat. JIPI (Jurnal Ilmu Perpustakaan dan Informasi) Vol. 2, No. 1. http://jurnal.uinsu.ac.id/index.php/jipi/article/view/919

B. Kitchenham and S. Charters. (2007). Guidelines for performing Systematic Literature Reviews in Software Engineering, In Technical report, Ver. 2.3 EBSE Technical Report.

C. Okoli and K. Schabram. (2010). A Guide to Conducting a Systematic Literature Review of Information Systems Research, Sprouts: Working Papers on Information Systems, Vol. 10 (26), 1-51

Daini, Helmi, Marlini. (2017). Pembuatan Standard Operating Procedure (SOP) Pengelolaan Arsip Dinas Kearsipan dan Perpustakaan Provinsi Sumatera Barat. Ilmu Informasi Perpustakaan dan Kearsipan Vol. 6, No. 1. DOI: 10.24036/8382-0934

Damara, Erba Adli, Arfa, Mecca. (2018). Aplikasi Manajemen Surat Untuk Pengelolaan Arsip Dinamis Aktif Di Pt Pln (Persero) App Salatiga. Jurnal Ilmu Perpustakaan Vol. 7, No. 1. https://ejournal3.undip.ac.id/index.php/jip/article/view/22825

Fitriani, Yuni, Pakpahan, Roida. (2018). Aplikasi Sistem Informasi Pengelolaan Arsip pada Unit Pelayanan Pajak dan Retribusi Daerah Palmerah Jakarta. Paradigma - Jurnal Komputer dan Informatika Vol. 20, No 2. DOI: 10.31294/p.v20i2.3991

Habiburrahman. (2016). Penggunaan Perangkat Lunak Dalam Pengelolaan Arsip Konvensional Dan Elektronik. JIPI (Jurnal Ilmu Perpustakaan dan Informasi) Vol. 1, No. 2. DOI: 10.30829/jipi.v1i2.559

Hamdani, Revi, Marlini. (2016). Sistem Pengelolaan Arsip Debitur di PT Bank Negara Indonesia (Persero) Tbk. Kantor Cabang Utama Padang. Ilmu Informasi Perpustakaan dan Kearsipan Vol. 5, No. 1. DOI: 10.24036/7192-0934

Hariyanto, Slamet. (2015). Model Mekanisme Pengelolaan Arsip Di Kantor Perpustakaan, Arsip Dan Dokumentasi Kabupaten Tulungagung. Jurnal PUBLICIANA Vol. 8, No 1. http://jurnalunita.org/index.php/publiciana/article/view/41

Harsini, Harsini, Nasution, Sri Roserdevi (2017). Pengelolaan Arsip Pada Aparatur Kelurahan Muara Fajar Barat Kecamatan Rumbai Kota Pekanbaru. Dinamisia : Jurnal Pengabdian Kepada Masyarakat Vol. 1 No. 1. DOI: 10.31849/dinamisia.v1i1.432

Imasita, Gunawan, Andi, Hirman. (2015). Pengembangan Model Pengelolaan Arsip (Surat) dan Dokumen Pemerintah Berbasis Web pada Kantor Pemerintah Kabupaten Sidrap Provinsi Sulawesi Selatan. Sainsmat Vol. 4, No. 2. DOI: 10.2685/sainsmat4218702015

Indriani, Vivi. (2018). Pengelolaan Arsip Di Sekolah Tinggi Ilmu Hukum Sumpah Pemuda Palembang. IQRA: Jurnal Perpustakaan dan Informasi Vol. 12, No. 1. http:// jurnal.uinsu.ac.id/index.php/iqra/article/view/1819

Iskandar. (2018). Reorientasi Sistem Pengelolaan Arsip Dinamis. JIPI (Jurnal Ilmu Perpustakaan dan Informasi) Vol. 3, No. 1. DOI: 10.30829/jipi.v3i1.1655

Iskandar, Danu Putra. (2015). Persepsi Pegawai Terhadap Pengelolaan Arsip Di Kantor Kejaksaan Negeri Bukittinggi. Jurnal Bahana Manajemen Pendidikan Vol. 3, No. 1. DOI: 10.23036/bmp.v3i1.5194

Jumiyati, Emi. (2015). Pengelolaan Arsip PTBBN Dalam Pelaksanaan Reformasi Birokrasi Batan. PIN - Pengelolaan Instalasi Nuklir Vol. 8, No. 15. http://jurnal.batan.go.id/ index.php/pin/article/view/2494

Juwita, Lasmi, Rahmah, Elva. (2016). Sistem Pengelolaan Arsip Unit dalam Negeri dan Kliring di PT Bank Negara Indonesia (Persero) Tbk Kantor Cabang Utama Padang. Ilmu Informasi 
Kafatan, Silmi, Riyanto, Djalal Er, Saputra, Ragil. (2014). Sistem Informasi Pengelolaan Arsip Statis Pada Badan Arsip Dan Perpustakaan Provinsi Jawa Tengah Menggunakan Vector Space Model. Jurnal Masyarakat Informatika Vol. 5, N.o. 9. DOI: https://doi.org/10.14710/ jmasif.5.9.45-52

Laksamana, Febrina Putri, Perdanakusuma, Andi Reza, Saputra, Mochamad Chandra. (2018). Evaluasi Biaya Pengembangan Sistem Informasi Pengelolaan Arsip Surat (SIPAS) Menggunakan Function Point dan Object Point (Studi Kasus : PT Sekawan Media Informatika). Jurnal Pengembangan Teknologi Informasi dan Ilmu Komputer Vol. 2 No. 8. http://j-ptiik.ub.ac.id/index.php/j-ptiik/article/view/1929

Lasambouw, Irma Fajriani, Kurniasih, Novi. (2016). Pengelolaan Arsip Vital pada Kantor Arsip Universitas Indonesia. Utilitas Vol. 2 No. 1. http://utilitas.uhamka.ac.id/index.php/utilitas/ article/view/37

Leidiyana, Henny, Ridwan, Deval Saladin. (2019). Aplikasi Pengelolaan Arsip Inaktif Berbasis Android pada Kantor Pusat Direktorat Jenderal Bea dan Cukai. Jurnal Abdimas BSI: Jurnal Pengabdian Kepada Masyarakat Vol. 2, No. 1. http://ejournal.bsi.ac.id/ejurnal/index.php/ abdimas/article/view/4775

M. Petticrew and H. Roberts. (2006). Systematic Reviews in the Social Sciences: A Practical Guide, Blackwell Publishing.

Muhidin, Sambas Ali, Winata, Hendri, Santoso, Budi. (2016). JPBM (Jurnal Pendidikan Bisnis dan Manajemen) Vol. 2, No. 3. http://journal2.um.ac.id/index.php/jpbm/article/ view/1708

Munawaroh, Faridatul. (2018). Pengawasan Kepala Sekolah Terhadap Pengelolaan Arsip Di Sekolah. Al-Afkar : Jurnal Keislaman \& Peradaban Vol. 6, No. 1. Al-Afkar : Jurnal Keislaman \& Peradaban Vol 6, No 1

Mustika, Reni (2018). Pengelolaan arsip di detik Sumatera Selatan. IQRA: Jurnal Perpustakaan dan Informasi Vol. 12, No. 1. http://jurnal.uinsu.ac.id/index.php/iqra/article/view/1855

Nugraha, Januar Adi, Widiyanto, Andi, Primadewi, Ardhin. (2018). Sistem Pengelolaan Arsip Dengan Menerapkan Manajemen Akses User Berbasis Web Pada YPPALB B (Tunarungu Wicara) Kota Magelang. Jurnal Komtika Vol. 2 No. 1. http://journal.ummgl.ac.id/ index.php/komtika/article/view/2112

Nuraini. (2018). Pengelolaan Arsip Statis pada Badan Perpustakaan, Arsip dan Dokumentasi Provinsi Sumatera Utara. JIPI (Jurnal Ilmu Perpustakaan dan Informasi) Vol. 3, No. 1. DOI: 10.30829/jipi.v3i1.1654

Putri, Desi. (2016). Pengelolaan Arsip Di Kantor Badan Pengendalian Dampak Lingkungan Daerah Kota Padang. Jurnal Bahana Manajemen Pendidikan Vol. 4, No. 1. DOI: 10.23036/ bmp.v4i1.5962

Rahmawati, Nita, Ismiyati. (2016). Pengelolaan Arsip Inaktif Dalam Upaya Mendukung Layanan Informasi Di Kantor Arsip Dan Perpustakaan Daerah Kabupaten Purworejo. Economic Education Analysis Journal Vol. 5 No. 1.

Ramadani, Ramdani. (2018). Pengelolaan arsip dinamis (surat masuk dan surat keluar) di Universitas Indo Global Mandiri. IQRA': Jurnal Perpustakaan dan Informasi Vol. 12, No. 02. http://jurnal.uinsu.ac.id/index.php/iqra/article/view/3987

Rifauddin, Machsun. (2016). Pengelolaan Arsip Elektronik Berbasis Teknologi. Khizanah alHikmah : Jurnal Ilmu Perpustakaan, Informasi, dan Kearsipan Vol. 4, No. 2. DOI: 10.24252/ kah.v4i27

Robby Yuli Endra, Usman Rizal, Fenty Ariani. (2016). E-Arsip Berbasis Image Archives Management Process Model untuk Meningkatkan Efektifitas Pengelolaan Arsip. Explore Vol. 7, No. 1. http://jurnal.ubl.ac.id/index.php/explore/article/view/768 
Sadhyoko, Joseph Army (2018). Menciptakan Pengelolaan Arsip Surat Kabar yang Andal (Studi Kasus Depo Arsip Suara Merdeka). Khazanah: Jurnal Pengembangan Kearsipan Vol. 9, No. 2. DOI: $10.22146 /$ khazanah.22891

Soesilo, S. (2017). Optimalisasi Pengelolaan Kearsipan Melalui Arsip-E Di Direktorat Jenderal Guru Dan Tenaga Kependidikan. Manajerial Vol. 16, No. 2. http://ejournal.upi.edu/ index.php/manajerial/article/view/12780

Suhana. (2016). Pengaruh Sumber Daya Manusia Dan Ruang Penyimpanan Arsip Dalam Melakukan Kegiatan Pengelolaan Kearsipan Di Pusat Reaktor Serba Guna. Reaktor Buletin Pengelolaan Reaktor Nuklir Vo. 13, No. 1. DOI: 10.17146/bprn.2016.v13i1.3884

Suyono, Suyono, Kadir, Abdul (2014). Fungsi Pengelolaan Arsip Dalam Rangka Meningkatkan Efektivitas Kerja Pada Balai Pengelolaan Hutan Mangrove Wilayah II. Publikauma : Jurnal Administrasi Publik Universitas Medan Area Vol. 2, No. 2. DOI: 10.31289/ publika.v2i2.1407

Tjiptasari, Fitriana. (2017). Persepsi kegunaan pengelolaan arsip digital menggunakan SIKD (sistem informasi kearsipan dinamis). Jurnal Kajian Informasi dan Perpustakaan Vol. 5, No. 2. DOI: $10.24198 /$ jkip.v5i2.12645

Yanti, Rani Nova, Nelisa, Malta. (2014). Pengelolaan Arsip Dinamis Inaktif di Kantor Dinas Koperasi dan Usaha Mikro Kecil dan Menengah (UMKM) Provinsi Sumatera Barat. Ilmu Informasi Perpustakaan dan Kearsipan Vol. 3, No. 1. DOI: 10.24036/5715-0934

Yona, Oktri, Marlini, Marlini. (2016). Penggunaan System Application and Product in Data Processing (SAP) dalam Pengelolaan Data Arsip pada Bagian Keuangan PT Telkom Witel Sumbar. Ilmu Informasi Perpustakaan dan Kearsipan Vol. 5, No. 1. DOI: 10.24036/71900934

Yusron, Ali. (2019). Upaya Meningkatkan Kinerja Pegawai Tata Usaha (TU) Dalam Pengelolaan Arsip Melalui Kegiatan Supervisi Manajerial Pada Madrasah Tsanawiyah Swasta Darul Istiqomah Padangsidempuan. Jurnal Education and Development Vol. 7 No. 1. http:// journal.ipts.ac.id/index.php/ED/article/view/832

Zakiah, Azizah, Supriatna, Apit. (2015). Aplikasi Pengelolaan Arsip Surat Berdasarkan Peraturan Bersama Kepala Anri Nomor 18 Th. 2009. Sentia 2015 Vol. 7, No. 2. http:// sentia.polinema.ac.id/index.php/SENTIA2015/article/view/193 